\title{
INTERFERENSI BAHASA MELAYU TERHADAP BAHASA INDONESIA PADA TKI DI DUSUN GETAP KECAMATAN SURALAGA (KAJIAN SOSIOLINGUISTIK)
}

\author{
Dian Aprila Diniarti ${ }^{1}$; Amrulloh ${ }^{2}$; Syahdan $^{3}$ \\ ${ }^{1}$ Mahasiswa Pascasarjana Universitas Mataram, NTB, Indonesia \\ ${ }^{2,3}$ Dosen Pascasarjana Universitas Mataram, NTB, Indonesia \\ dianarti26@gmail.com
}

\begin{abstract}
Issues to be examined in this study is the cause of interference Malaysia language to Indonesian language performed by TKI Malaysia in subdistrict Suralaga and how is the form of interference against Indonesian Malay them. Malaysia migrant workers who had returned to his hometown Malaysia tends to insert language into the Indonesian language usage when they are invited to do a conversation Indonesian. Based on these problems, the objectives of this research was to determine the causes and forms of language interference undertaken by TKI Malaysia in subdistrict Suralaga. This type of research is qualitative descriptive. While data collection techniques done by tapping and interview techniques. Data were recorded and then transcribed in writing and analyzed using the model of Miles and Huberman. Based on the analysis that has been done, it can be drawn the conclusion that the cause of the interference on TKI Malaysia language is social, the habit of using the Malay language when communicating, and the length of a migrant worker. While the forms of language interference that occurs is the interference of phonology, morphology, and syntax.
\end{abstract}

Keywords: Interference, Malay Language, Indonesian language

\section{PENDAHULUAN}

Dalam kehidupan sosial, kita mengetahui adanya masyarakat yang terbuka, artinya para anggota masyarakat tersebut dapat menerima kedatangan dari anggota masyarakat lain. Bahasa dari masyarakat yang menerima kedatangan akan saling mempengaruhi dengan bahasa dari masyarakat yang datang. Dari peristiwa penerimaan tersebut, maka akan terjadi apa yang disebut kontak bahasa. Hal yang paling menonjol dari adanya kontak bahasa antara masyarakat yang satu dengan masyarakat yang lain adalah terjadinya bilingualisme dan multilingualisme. Terjadinya kontak bahasa akan mempengaruhi bahasa yang berkontak, dan pengaruh kontak bahasa tersebut adalah terjadinya integrasi dan interferensi.

Istilah interferensi pertama kali digunakan oleh Weinreich untuk menyebut adanya perubahan sistem suatu bahasa sehubungan dengan adanya persentuhan bahasa tersebut dengan unsur-unsur bahasa lain yang dilakukan oleh penutur yang bilingual (Chaer dan Agustina, 2010: 120). Penutur bilingual maksudnya di sini adalah orang 
yang mampu atau bisa menggunakan dua bahasa, dan lazimnya dalam bahasa Indonesia disebut dwibahasawan. Sedangkan kemampuan menggunakan dua bahasa disebut bilingualism.

Warga Negara Indonesia adalah bilingual, karena sebagian besar masyarakat Indonesia menguasai lebih dari satu bahasa. Dua bahasa yang dimaksud di sini adalah bahasa pertama yang disingkat ( B1) adalah bahasa ibu yang didapat pertama kali, dan yang kedua adalah bahasa kedua yang disingkat (B2) adalah bahasa yang didapat setelah bahasa ibu. Bisa jadi B2 yang didapat adalah bahasa Indonesia atau bahasa asing. Contohnya saja masyarakat pedesaan yang B1 nya adalah bahasa ibu, ada juga B2 nya bahasa asing. Hal tersebut dikarenakan kurang mampunya orang tua untuk membiayai anaknya sekolah sehingga anak tersebut tidak mendapatkan pendidikan untuk memperoleh bahasa Indonesia sebagai B2 nya.

Seperti fenomena yang sering kita lihat bahwa masyarakat pedesaan banyak sekali yang menjadi TKI di Malaysia. Bahkan ada juga TKI yang bekerja di Malaysia sampai 5 tahun tanpa paspor (gelap). Akibat lamanya menjadi TKI di Malaysia, penggunaan bahasa Indonesia mereka menjadi tidak gramatikal. Ketika mereka diajak berbahasa Indonesia, mereka cenderung lebih menggunakan bahasa Malaysia dibanding bahasa Indonesia yang merupakan bahasa negaranya sendiri. Hal ini dikarenakan bahasa yang diperoleh setelah bahasa ibu adalah bahasa asing atau bahasa Malaysia itu sendiri.

Antara bahasa Malaysia dengan bahasa Indonesia memang tidak jauh berbeda, karena kedua bahasa tersebut terbentuk dari bahasa Melayu. Namun, tidak semua kosakata bahasa Malaysia sama maknanya dengan bahasa Indonesia. Salah satunya kata "pusing" yang dalam bahasa Malaysia artinya "putar", sedangkan dalam bahasa Indonesia memiliki arti "sakit kepala". Dari kata tersebut akan menimbulkan makna yang berbeda sehingga membuat orang yang mendengar akan salah persepsi. Peristiwa seperti inilah yang disebut sebagai interferensi.

Penelitian ini menggunakan pendekatan sosiolinguistik karena bidang ilmu ini mengkaji bahasa dalam penggunaannya di masyarakat. Banyak sekali interferensi bahasa yang dilakukan oleh para TKI yang baru pulang dari Malaysia, baik itu interferensi dari segi fonologi, morfologi, maupun sintaksis. Semua interferensi tersebut dilakukan dalam bentuk kalimat yang diucapkan dengan lisan oleh penutur bilingual. 


\section{TEORI DAN METODOLOGI}

Penelitian yang digunakan adalah deskriptif kualitatif. Jenis penelitian deskriptif merupakan jenis penelitian yang menekankan pada observasi dan keadaan atau fenomena-fenomena yang terjadi dalam masyarakat secara alamiah. Artinya, data yang dikumpulkan berasal dari lingkungan yang nyata dan apa adanya, yaitu tentang penyebab dan bentuk interferensi bahasa.

Penelitian deskriptif kualitatif tidak dimaksudkan untuk menguji suatu hipotesis tertentu, tetapi hanya menggambarkan apa adanya tentang suatu variabel, gejala atau keadaan. Dalam penelitian ini data yang terkumpul berupa kata dan kalimat, bukan dalam bentuk angka. Oleh karena itu, penelitian ini menggunakan pendekatan kualitatif. "Pendekatan kualitatif memiliki ciri-ciri, yaitu; memiliki sifat deskriptif analitik, tekanan pada proses bukan hasil, bersifat induktif, dan mengutamakan makna" (Depdiknas dalam Alwi dkk, 2013: 28).

Data dalam penelitian ini adalah data verbal yang berupa ucapan lisan yang merupakan penyebab dan bentuk interferensi. Sedangkan sumber data dalam penelitian ini adalah para TKI Malaysia yang ada di Dusun Getap Kecamatan Suralaga.

Dalam penelitian ini, pengumpulan data dilakukan dengan teknik rekam suara dan mencatat kata dan kalimat yang merupakan penyebab dan bentuk interferensi. Adapun teknik pengumpulan data dilakukan dengan cara sebagai berikut:

1. Teknik Sadap dan Wawancara

Teknik sadap adalah teknik pengumpulan data yang dilakukan secara sembunyi tanpa diketahui oleh pihak lain. Teknik ini digunakan untuk mendapatkan informasi yang dibutuhkan oleh peneliti untuk penelitiannya. Dalam penelitian ini, peneliti menggunakan teknik sadap, yaitu merekam secara sembunyi peristiwa percakapan antar TKI Malaysia, agar bentuk interferensi bisa terlihat. Selain itu, untuk mendapatkan penyebab interferensi, peneliti menggunakan wawancara tidak terstruktur. Artinya, peneliti melakukan wawancara dengan menggunakan bahasa Indonesia dan bahasa daerah setempat.

\section{Enumerator (Asisten Peneliti)}

Untuk memperoleh data, peneliti mendapatkan bantuan dari keluarga peneliti yang juga TKI Malaysia. Orang yang membantu peneliti untuk mendapatkan data disebut enumerator atau disebut juga dengan asisten peneliti. Tugas enumerator dalam 
penelitian ini, yaitu mengajak TKI Malaysia berkomunikasi dengan hal-hal yang biasa dibicarakan oleh TKI Malaysia ketika berada di Malaysia serta merekam percakapan yang sedang berlangsung. Setelah proses pembicaraan tersebut selesai, enumerator kemudian memberikan data yang sudah direkam kepada peneliti. Selain itu data utama diperoleh dari para TKI Malaysia yang menjadi informan pada penelitian ini.

Syarat-syarat penentuan informan adalah sebagai berikut.

a. Tidak mengalami cacat alat ucap.

b. Sehat jasmani dan rohani.

c. Pernah menjadi TKI di Malaysia

d. Memahami betul hal-hal yang biasa dibicarakan oleh para TKI Malaysia

e. Memiliki pengalaman yang cukup ketika merantau di Malaysia

3. Transkrip Data

Jika kita melihat KBBI, kata transkrip diartikan sebagai salinan. Sesuai dengan teknik pengumpulan data yang dilakukan peneliti pada penelitian ini, yaitu teknik rekam suara, maka transkrip data pada penelitian ini yaitu dengan menyalin bentuk rekam suara yang telah dilakukan ke dalam bentuk tulisan. "Semua hasil wawancara dan diskusi rekam dengan audio tape, video, dan catatan lapangan kemudian ditransfer ke dalam disket/ flasdisk atau bentuk lainnya" (Patilima, 2011: 95). Bentuk lain yang dimaksud oleh Patilima yaitu bisa berupa hasil rekaman yang dipindah atau disalin ke dalam bentuk catatan atau teks.

\section{PEMBAHASAN HASIL PENELITIAN}

Data yang dideskripsikan dalam penelitian ini yaitu untuk menganalisis penyebab serta bentuk interferensi bahasa Melayu Malaysia terhadap bahasa Indonesia yang dilakukan oleh para TKI Malaysia yang ada di Dusun Getap Kecamatan Suralaga dengan cara pengumpulan data dengan teknik rekam suara. Adapun data-data yang dideskripsikan yaitu transkripsi data yang termasuk ke dalam penyebab dan bentuk interferensi fonologi, morfologi, dan sintaksis. 
Beberapa transkripsi data tersebut akan disajikan sebagai berikut.

\section{Transkrip 1 ( T1)}

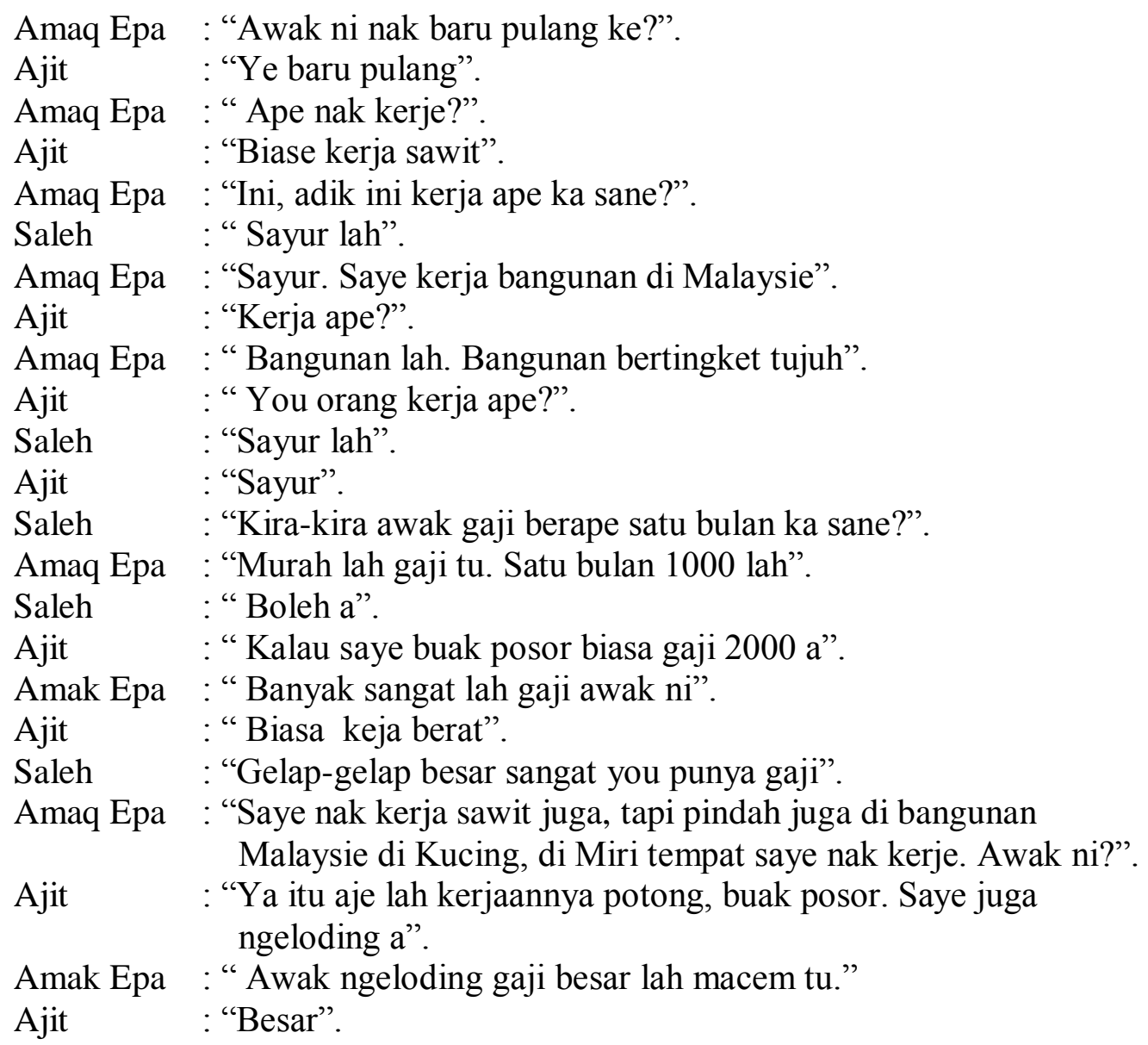

\section{Transkrip 2 (T2)}

Mif : "Bang macem mane ketika dicakok ular tu macem mane keadaan ka sane?".

Tablek : "Biase je. Tak de lah kene sakit-sakit sangat".

Mif : "E..Aku dengar dekak kawan pun abang masuk hospital ada pun ka sane".

Tablek : "Masuk hospital itu memang lah, tapi tak bawa duik".

Mif : : O..Mane lah saye tahu. Kenape abang tak call saye?".

Tablek : "Mane boleh call masuk hospital, orang tengah sakit".

Mif : "Ye lah. Abang tak call kita risau lah ka rumah. Bos you pun cari ka rumah. Aku pun risau lah".

Tablek : :Itu benda lame lah, nak cakap macem mane lagi. Sudah lah".

\section{Transkrip 3 (T3)}

Kadir : "Awak ka mane?".

Muk : :Tempat je". 


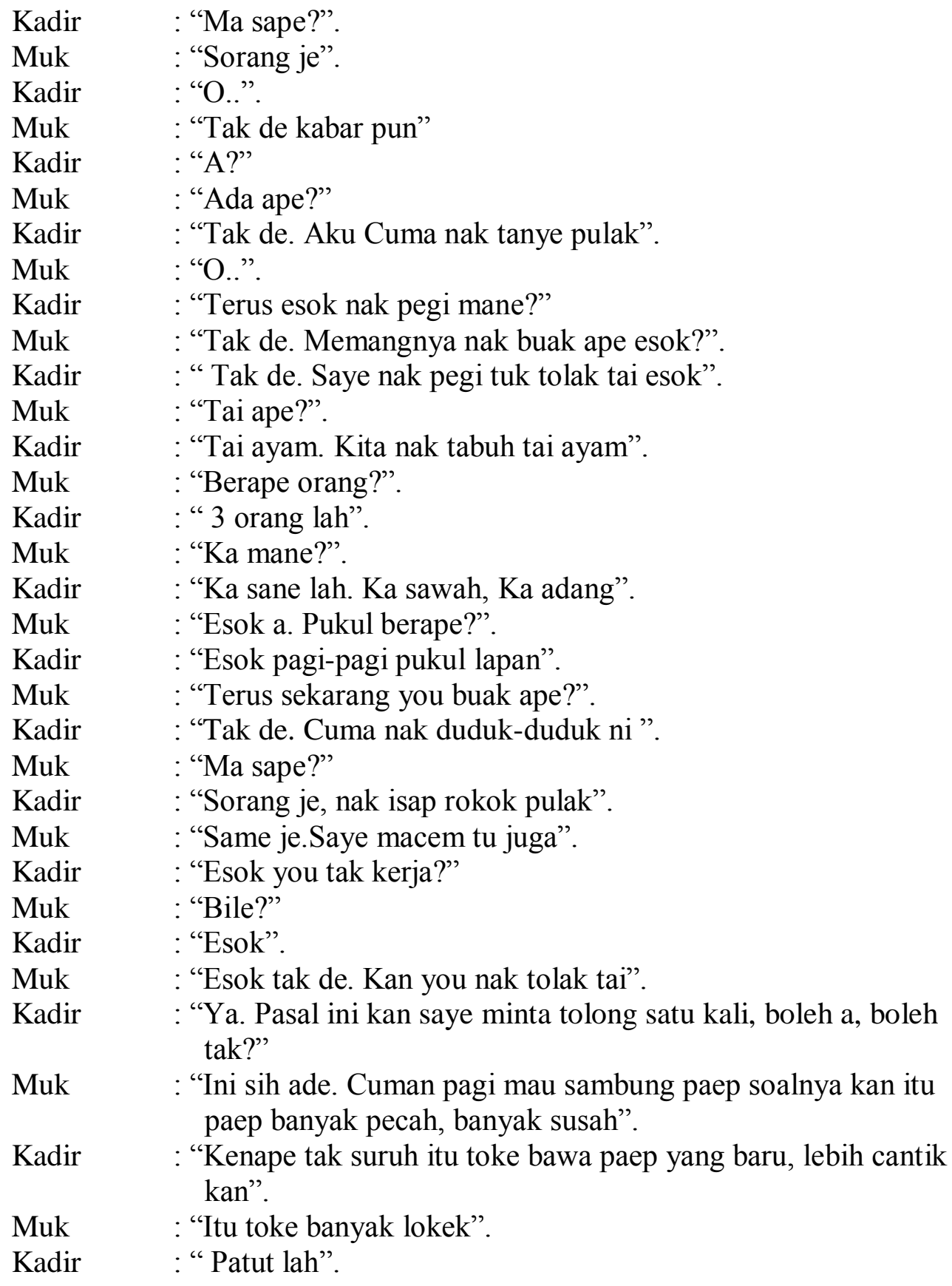

\section{Transkrip 4 (T4)}

Dian : "Kira-kira bagaimana pengalaman anda ketika berada di Malaysia?”.

Mif : "Oke je. Ka sane oke sangat. Kawan banyak. Kita pun kerja banyak. Seronok lah".

Dian : "Terus bagaimana tentang pekerjaan anda di sana?".

Mif : "Mm..Baik".

Dian : "Apakah ada pengalaman-pengalaman yang memang anda tidak tidak bisa lupakan?”. 


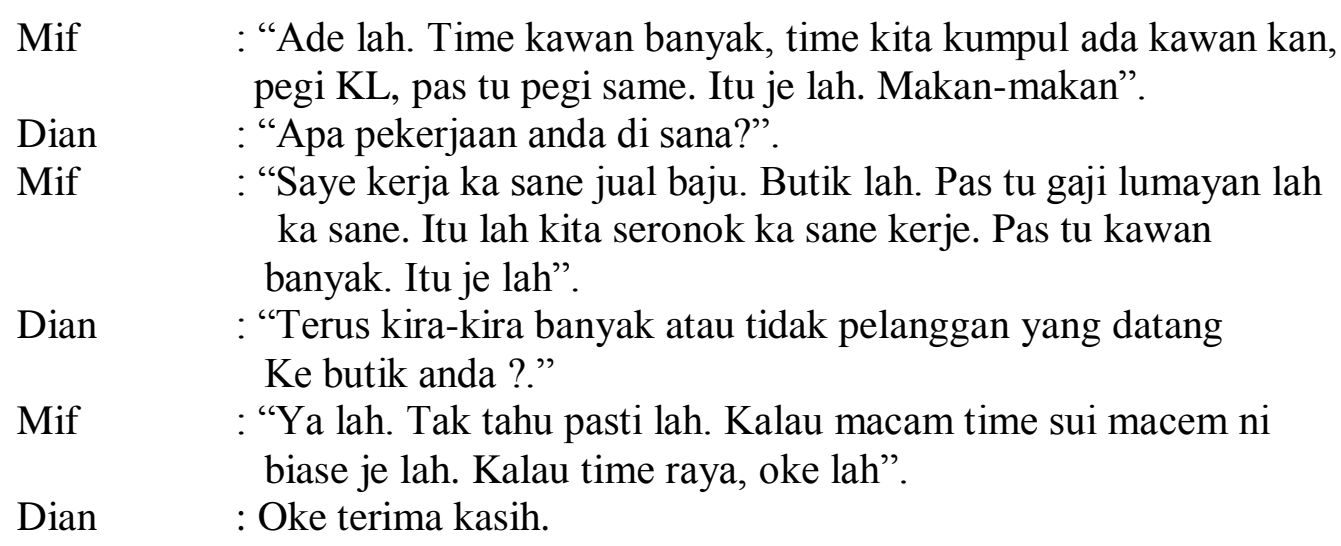

\section{Transkrip 5 (T5)}

Peno : "Dulu waktu saye di Gembrot ada monyet lagi begini".

Agus+Subli : "Ha..ha..ha".

Peno : : "Ini kan lagi ini, minum apa itu, cola yang di kaleng itu plastiknya die gendong di atas monyong-monyong".

Agus : : "Benar kah dia merokok ni. Apa tipu-tipu ni?".

Peno : "Benar. Mana tipu. Memang monyet mulutnya monyong kok".

Amaq Ayi : "Memang benar dia merokok. Dulu di Meradang pun macam itu dia curu-curi rokok. Dua bungkus, tiga bungkus tu hari-hari dia curi rokok. Kawan-kawan pun bising semua. Mana Yi saya punya rokok? Gitu. Tahu? Mi diambil, telur".

Agus : :Kok doyan telur. Dia goreng kah telur?".

Amaq Ayi : "Mana tahu. Langsung diembat".

Agus : "Hebat".

Amaq Ayi : "Buahari punya rokok itu digigit-gigit terus ditaruh".

Subli : "Siape?".

Agus : "Monyet".

Amak Ayi : "dibuka bungkusnya digigit-gigit terus dimasukkan lagi"

Subli : :Memang nakal betul lah monyet sana".

Amak Ayi : "Ada yang dipatahin. Setelah dipatah-patahin digigit-gigit".

Subli : "Tapi dia buka ini wak, penggorengan-penggorengan orang dia buka-buka wak".

Peno : "Mulai dari sana orang simpen barangnya kuat-kuat".

\section{Transkrip 6 (T6)}
Dian : "Pira taon peka Malaysia kak?". ( Berapa tahun kakak di Malaysia?).
Kadir : "Empat taon ahtenga".
( Empat setengah tahun ).
Dian : "Epe jak makdi Epa pira taon peka ito?".
( Kalau paman Epa berapa tahun di sana?).
Amaq Epa : “Dua taon”.
( Dua tahun ).
Dian : "Biasa kan gitak ta dengan-dengan i wah meratno timpak


Malaysia no lamunta tenak ya basa Indonesia no pasti arak doang tama na basa Malaysia na, bahkan pol basa Malaysia kaduna endah".

( Seperti yang biasa kita lihat bahwa orang-orang yang pernah merantau ke Malaysia kalau diajak menggunakan bahasa Indonesia pasti ada bahasa Malaysia yang masuk ke dalam bahasa Indonesia nya, bahkan ada yang cenderung menggunakan bahasa Malaysia seluruhnya ).

Kadir : "Kira-kira pergaulanta nono jak. Pergaulanta bareng dengan Melayu, ta ngeraos bareng bos ta no harus ta ngadu basa ito soal na yakna ngerti gin basanta jari harus ta ngadu basa ito".

( Kira-kira pergaulan kita. Pergaulan kita dengan orang Melayu, ketika kita berbicara dengan bos harus kita pakai bahasa sana, soalnya mereka tidak mengerti dengan bahasa kita Jadi kita harus menggunakan bahasa sana ).

Amaq Epa : "Wah kdung biasanta ngadu basa ito no ahirna milu doang ya basa Malaysia no lamunta basa Indonesia no".

( Karena kita sudah terbiasa menggunakan bahasa sana akhirnya ikut saja bahasa Malaysia itu ketika kita menggunakan bahasa Indonesia ).

Dian : "O ngto ke".

( $O$ begitu ya ).

\section{Transkrip 7 (T7)}

\begin{tabular}{|c|c|}
\hline Dian & $\begin{array}{l}\text { : "Pira taon peke ito Malaysia?". } \\
\text { ( Berapa tahun Anda di Malaysia?). }\end{array}$ \\
\hline Mif & $\begin{array}{l}: \text { " } 2 \text { taon ku ito". } \\
\text { ( } 2 \text { tahun }) .\end{array}$ \\
\hline Dian & $\begin{array}{l}\text { : “O.. } 2 \text { taon. Epe jak nak Ubaq?”. } \\
\text { (O.. } 2 \text { tahun. Kalau Ubaq bagaimana? ). }\end{array}$ \\
\hline Ubaq & $\begin{array}{l}: \text { "3 taon". } \\
\text { (3 tahun). }\end{array}$ \\
\hline Dian & $\begin{array}{l}\text { : "Kumbenake pe pada girang ngadu basa Malaysia? Maksud } \\
\text { ku no bilang pe tenak basa Indonesia arak doang ke tama basa } \\
\text { Malaysia no?". } \\
\text { (Kenapa kalian sering memakai bahasa Malaysia? Maksud saya } \\
\text { setiap kalian diajak menggunakan bahasa Indonesia pasti ada saja } \\
\text { bahasa Malaysia yang masuk). }\end{array}$ \\
\hline Mif & $\begin{array}{l}\text { : "Mba wah biasanta ito no yak na mele lupak. Arak doang ka } \\
\text { Legot-legot ta bahasa Melayu. Ya beng ita bahasa Malaysia } \\
\text { doang no. Terus ta layan dengan belanja no basa Melayu, ta } \\
\text { lawan Bos ta no basa Melayu. Ya beng ita biasa". } \\
\text { (Karena sudah biasa jadi tidak bisa lupa. Ada saja logat-logat } \\
\text { bahasa Melayu. Itu yang menyebabkan kita menggunakan } \\
\text { bahasa Malaysia terus. Saat melayani orang belanja pakai } \\
\text { bahasa Melayu, bicara dengan Bos pakai bahasa Melayu. } \\
\text { Itu yang menyebabkan kita biasa). }\end{array}$ \\
\hline
\end{tabular}




\section{Pembahasan penyebab terjadinya interferensi pada TKI Malaysia}

Dari hasil observasi dan penelitian yang telah dilakukan peneliti, dapat dilihat bahwa penyebab terjadinya interferensi bahasa Melayu Malaysia terhadap bahasa Indonesia pada TKI di Kecamatan Suralaga ada tiga.

\section{a. Pergaulan dengan orang Melayu}

Ketika berada di Malaysia para TKI berinteraksi dengan masyarakat setempat, sehingga menuntut mereka untuk menggunakan bahasa Melayu agar pergaulan dan proses komunikasi yang terjadi antar mereka bisa berjalan dengan lancar. Hal tersebut dinyatakan oleh para TKI pada T6. Menurut pernyataannya, mereka harus menggunakan bahasa Malaysia ketika bergaul dengan orang Melayu dan berkomunikasi dengan bos mereka. Sebab, jika mereka menggunakan bahasa mereka sendiri, orang Melayu dan bos mereka tidak akan mengerti dengan bahasa yang mereka gunakan. Hal tersebut menuntut para TKI Malaysia untuk menggunakan bahasa Malaysia ketika bergaul dan berinteraksi.

\section{b. Kebiasaan menggunakan bahasa Malaysia ketika berkomunikasi}

Kebiasaan menggunakan bahasa Malaysia ketika berada di Malaysia membuat para TKI tidak bisa melupakan bahasa tersebut, sehingga setiap berbicara menggunakan bahasa Indonesia, pasti ada serpihan bahasa Malaysia yang masuk ke dalam bahasa Indonesia yang sedang digunakan. Hal tersebut dinyatakan oleh para TKI pada T6 dan T7. Menurut pernyataan mereka, menggunakan bahasa Malaysia sudah menjadi suatu kebiasaan untuk berkomunikasi ketika berada di Malaysia, sehingga membuat para TKI sulit untuk melupakan bahasa tersebut.

\section{c. Lamanya menjadi TKI di Malaysia.}

Lamanya menjadi TKI di Malaysia membuat para TKI menguasai bahasa Malaysia meski pun tidak begitu sempurna. Pergaulan dan kebiasaan menggunakan bahasa Malaysia membuat bahasa tersebut tidak mudah untuk dihilangkan dari para TKI. Terlebih bagi mereka yang tidak mendapatkan bahasa Indonesia sebagai B2-nya, sehingga tanpa disadari para TKI Malaysia memperoleh bahasa Malaysia sebagai B2nya. Chaer dan Agustina (2010: 86) "mengatakan bahwa seseorang yang terlalu lama tinggal dalam masyarakat tutur B2-nya (terlepas dari masyarakat tutur B1-nya), akan mempunyai kesempatan yang lebih luas untuk menggunakan B2-nya daripada B1-nya”. 


\section{Pembahasan bentuk interferensi bahasa pada TKI Malaysia}

Bentuk interferensi bahasa Malaysia terhadap bahasa Indonesia yang dilakukan oleh TKI Malaysia yang ada di Kecamatan Suralaga terdiri atas tiga bentuk yaitu interferensi fonologi, morfologi, dan sintaksis.

Adapun bentuk-bentuk interferensi tersebut akan disajikan sebagai berikut.

\section{a. Interferensi Fonologi}

Beberapa bentuk interferensi fonologi bahasa Melayu Malaysia terhadap bahasa Indonesia yang dilakukan oleh para TKI Malaysia yang ada di Kecamatan Suralaga, yaitu:

\section{Perubahan fonem vokal}

Tabel perubahan fonem vokal

\begin{tabular}{|c|c|c|c|}
\hline BM & & \multicolumn{2}{|c|}{ BI } \\
\hline [sapə] /sape/ & $\longrightarrow$ & [siapa] & /siapa/ \\
\hline [samo] /same/ & $\longrightarrow$ & [sama] & /sama/ \\
\hline [apə] /ape/ & & [Apa] & /apa/ \\
\hline [sayㅁ] /saye/ & & [saya] & /saya/ \\
\hline [jugga] /juge/ & & [juga] & /juga/ \\
\hline [Iy므 /iye/ & $\longrightarrow$ & [Iya] & /iya/ \\
\hline [biasㅁ] /biase/ & & [biasa] & /biasa/ \\
\hline
\end{tabular}

Berdasarkan hasil penelitian di atas, dapat dikemukakan bahwa perubahan fonem vokal dari bahasa Malaysia ke dalam bahasa Indonesia terdapat pada akhir kata. Perubahannya terjadi menurut pola berikut .

\begin{tabular}{|c|c|c|c|}
\hline $\mathrm{BM}$ & & BI & Keterangan \\
\hline [ə] & $\rightarrow$ & [a] & Bila terletak pada suku ultima \\
\hline
\end{tabular}

\section{Perubahan fonem konsonan}

Tabel perubahan fonem konsonan

\begin{tabular}{|l|l|ll|}
\hline \multicolumn{2}{|c|}{ BM } & & \multicolumn{2}{|c|}{ BI } \\
\hline [bua? $]$ /buak/ & & & \\
\hline$[$ dui ] $/$ duik/ & $\longrightarrow$ & {$[$ buat $]$} & $/$ buat/ \\
\hline
\end{tabular}


Dari hasil penelitian yang telah dilakukan dapat dilihat perubahan fonem konsonan bahasa Malaysia ke dalam bahasa Indonesia. Fonem /k/ dalam bahasa Malaysia yang terletak di akhir kata diubah menjadi fonem /t/ dalam bahasa Indonesia. Perubahannya terjadi menurut pola berikut.

\begin{tabular}{|c|l|c|c|}
\hline BM & & BI & Keterangan \\
\hline [?] & $\rightarrow$ & {$[\mathrm{t}]$} & Bila terletak pada suku ultima \\
\hline
\end{tabular}

Pelesapan fonem vokal dan konsonan

Tabel pelesapan fonem vokal dan kosanan

\begin{tabular}{|c|c|c|}
\hline $\mathrm{BM}$ & & BI \\
\hline [lapan] /lapan/ & & [d_olapan] /delapan/ \\
\hline [isap] /isap/ & & [hisap] /hisap/ \\
\hline [adan] /adang/ & & [ladan] /ladang/ \\
\hline [esor] /esok/ & & [b esor] /besok/ \\
\hline [ta2] & & /tidak/ \\
\hline [pəgi] /pegi/ & & [porgi] \\
\hline [soran] /sorang/ & & /seorang/ \\
\hline
\end{tabular}

Dari hasil penelitian yang telah dilakukan dapat dilihat bahwa pelesapan fonem vokal dan konsonan bahasa Malaysia ke dalam bahasa Indonesia terletak pada suku pertama, kedua, dan ketiga kata. Pada suku pertama, kata [lapan] dilesapi fonem konsonan /d/ pada awal kata sehingga menjadi [dəlapan], kata [isap] dilesapi fonem konsonan /h/ sehingga menjadi [hisap], kata [adan] dilesapi fonem konsonan /1/ sehingga menjadi [ladan], kata [esor] dilesapi fonem konsonan /b/ sehingga menjadi [ $\underline{b}$ esər]. Pada suku kedua, kata [soran] dilesapi fonem vokal /e/ sehingga menjadi [səoran]. 
Pada suku ketiga, kata [pəgi] dilesapi fonem konsonan /r/ sehingga menjadi [pərgi], dan kata [ta2] dilesapi fonem vokal dan konsonan /i/ dan /d/ sehingga menjadi [tida?].

\section{b. Interferensi Morfologi}

\section{Prefiks $\{$ di- $\}$}

"Mane tahu, langsung diembat"

"Mana tahu, langsung dimakan"

Dari hasil penelitian yang telah dilakukan dapat dilihat awalan $\{$ di- $\}$ dalam bahasa Malaysia sejajar makna dan fungsinya dengan awalan $\{$ di- $\}$ dalam bahasa Indonesia sebagai prefiks pada kata verbal transitif.

\section{Klitik $\{$-nya $\}$}

"Memang monyet mulutnya monyong"

"Memang monyet mulutnya monyong"

Dari hasil penelitian yang telah dilakukan dapat dilihat kata "mulutnya" dalam bahasa Malaysia sejajar maknanya dengan kata "mulutnya" pada bahasa Indonesia karena termasuk golongan klitik dan morfem tersebut memiliki arti leksikal dan sudah jelas sama-sama mempunya pertalian arti dengan $i a$.

\section{Kata depan $\{$ di- $\}$}

"Saya kerja ka sane jual baju" "Saya kerja di sana jual baju"

Dari hasil penelitian yang telah dilakukan, dapat dilihat pemakaian kata depan $\{k a\}$ dalam bahasa Malaysia sejajar makna dan fungsinya sebagai penunjuk tempat dengan kata depan $\{$ di $\}$ dalam bahasa Indonesia.

\section{Pengulangan}

Interferensi bahasa Malaysia terhadap bahasa Indonesia dalam hal perulangan dapat ditemukan dalam dua bentuk, yaitu:

\section{1) Pengulangan seluruhnya}

"Dulu di Meradang pun macam tu dia curi-curi rokok"

"Dulu di Meradang juga seperti itu dia curi-curi rokok"

"Kawan-kawan pun bising semua"

"Kawan-kawan pun marah semua" 
Pengulangan seluruhnya ialah perulangan seluruh bentuk dasar, tanpa perubahan fonem dan tidak berkombinasi dengan proses pembubuhan afiks. Dari hasil penelitian yang telah dilakukan dapat dilihat pengulangan seluruhnya yang dilakukan para TKI dalam bahasa Malaysia sama bentuknya dengan perulangan dalam bahasa Indonesia.

\section{2) Pengulangan sebagian}

"Buahari punya rokok tu digigit-gigit"

"Rokoknya Buahari digigit-gigit"

Pengulangan sebagian ialah pengulangan sebagian dari bentuk dasarnya. Pengulangan sebagian yang dilakukan oleh TKI Malaysia dalam bahasa Malaysia sama dengan pengulangan sebagian dalam bahasa Indonesia. "Di sini bentuk dasar tidak diulang seluruhnya”(Ramlan, 2009: 70).

\section{c. Interferensi Sintaksis}

Bentuk interferensi sintaksis bahasa Melayu Malaysia terhadap bahasa Indonesia yang dilakukan oleh para TKI di Dusun Getap dapat dilihat dalam uraian contohcontoh berikut.

\section{Fungsi}

BM : Awak ni nak baru pulang ke?

$$
\text { S P }
$$

BI : $\underline{\text { Kamu ini baru pulang ya? }}$

$\mathrm{S}$

$\mathrm{P}$

BM : Saya kerja bangunan di Malaysie.
$\mathrm{S} \quad \mathrm{P}$
O Ket.tempat

BI : Saya kerja bangunan di Malaysia.
$\begin{array}{llll}\mathrm{S} & \mathrm{P} & \mathrm{O} & \text { Ket.tempat }\end{array}$

BM : Memang benar die merokok.

Ket.modalitas $\mathrm{S} \quad \mathrm{P}$ 
BI : Memang benar dia merokok.

Ket.modalitas $\mathrm{S} \quad \mathrm{P}$

BM : Esok you tak kerja?.

K.w $\quad \mathrm{S} \quad \mathrm{P}$

BI : Besok kamu tidak kerja?.

K.W $\quad \mathrm{S} \quad \mathrm{P}$

BM : Kawan-kawan pun bising semua.

$\mathrm{S} \quad \mathrm{P}$ Komp

BI : Kawan-kawan pun marah semua.

S P Komp

Dari hasil penelitian yang telah dilakukan dapat dilihat bahwa fungsi sintaksis bahasa Malaysia yang dilakukan TKI di Kecamatan Suralaga sama dengan fungsi sintaksis bahasa Indonesia. Hanya saja jika dilihat dengan seksama kalimat-kalimat tersebut, terdapat beberapa serpihan bahasa Malaysia yang masuk ke dalam bahasa Indonesia, contohnya pada kata [Malaysiə] yang menduduki fungsi K, kata [diə] dan [awa?] yang menduduki fungsi S, kata [bisIn] yang menduduki fungsi P. Jika diperhatikan, bahasa Malaysia memang tidak jauh berbeda dengan bahasa Indonesia karena memang kedua bahasa tersebut terbentuk dari satu bahasa yaitu bahasa Melayu. Hanya saja dalam bahasa Malaysia, hampir semua kata yang memiliki suku akhir fonem /e/ yang berbunyi [ə], dalam bahasa Indonesia diubah menjadi fonem /a/.

\section{Kategori}

BM : Besar sangat you punya gaji.

FV

BI : Besar sekali gaji kamu. 
BM : Kita nak tabuh tai ayam.

FN

BI : Kita akan menabur kotoran ayam.

FV

Dari hasil penelitian yang telah dilakukan dapat dilihat terjadi perubahan kategori sintaksis pada setiap frase yang memegang fungsi P. Pada contoh pertama, terdapat perubahan kategori frase verbal (FV) dalam bahasa Malaysia menjadi kategori frase nomina (FN) dalam bahasa Indonesia pada frase yang memegang fungsi P. Sedangkan pada contoh kedua, terjadi perubahan kategori frase nomina (FN) dalam bahasa Malaysia menjadi frase verba (FV) dalam bahasa Indonesia pada frase yang memegang fungsi $\mathrm{P}$.

\section{Peran}

BM : Besar sangat you punya gaji.

$$
\text { Ket.kuantitas } \mathrm{S}_{\text {penanggap }} \mathrm{P}_{\text {pemilikan }}
$$

BI : Gaji kamu besar sekali.

$$
\mathrm{S}_{\text {penanggap }} \quad \mathrm{P}_{\text {kuantitas }}
$$

BM : Buahari punya rokok digigit-gigit.

$$
\mathrm{S}_{\text {penanggap }} \mathrm{P}_{\text {pemilikan }} \mathrm{O}_{\text {sasaran }} \text { Komp pelengkap }
$$

BI : Rokoknya Buahari digigit-gigit.

$$
\mathrm{S}_{\text {penanggap }} \quad \mathrm{P}_{\text {tindakan }}
$$

Dari hasil penelitian yang telah dilakukan dapat dilihat perubahan peran sintaksis bahasa Malaysia ke dalam bahasa Indonesia. Pada contoh pertama, terjadi perubahan peran pada frase yang memegang fungsi P. Fungsi P pada bahasa Malaysia yang berperan "pemilikan" berubah menjadi peran "kuantitas" pada fungsi P dalam bahasa Indonesia. Sedangkan pada contoh kedua, terjadi perubahan fungsi Komplemen dalam bahasa Malaysia yang berperan "pelengkap" menjadi peran "tindakan" pada fungsi P dalam bahasa Indonesia.

Dilihat dari kemurnian bahasa, interferensi dari segi apa pun baik itu interferensi fonologi, morfologi, atau sintaksis merupakan suatu virus yang dapat merusak bahasa. Meskipun interferensi tidak dapat dihilangkan, namun terjadinya interferensi tersebut 
dapat diatasi. "Semakin tinggi tingkat pendidikan seseorang, semakin maju perekonomiannya, maka semakin kurang orang tersebut menghasilkan interferensi" (Aslinda dan Leni, 2010:83). Dari pendapat tersebut dapat disimpulkan bahwa situasi dan kondisilah yang menuntut seseorang untuk berbahasa Indonesia yang baik dan benar.

\section{SIMPULAN}

Dari hasil penelitian yang telah dilakukan maka dapat ditarik simpulan sebagi berikut:

1. Penyebab terjadinya interferensi pada TKI Malaysia yaitu, karena pergaulan para TKI dengan orang Melayu, kebiasaan menggunakan bahasa Malaysia ketika berkomunikasi di Malaysia, dan lamanya menjadi TKI di Malaysia.

2. Bentuk interferensi Bahasa Malaysia terhadap bahasa Indonesia yaitu, interferensi fonologi, morfologi, dan sintaksis. Interferensi fonologi terjadi dalam beberapa bentuk, yakni perubahan fonem vokal, perubahan fonem konsonan, dan pelesapan fonem vokal dan konsonan. Sedangkan interferensi morfologi terjadi dalam bentuk, yakni awalan $\left\{\mathrm{di}^{-}\right\}$dan klitik $\{$nya- $\}$, kata depan $\{\mathrm{di}\}$, pengulangan seluruhnya, dan pengulangan sebagian. Sedangkan Interferensi sintaksis pada TKI Malaysia yaitu masuknya serpihan bahasa Malaysia ke dalam bahasa Indonesia yang sedang digunakan pada fungsi, kategori dan peran.

\section{DAFTAR PUSTAKA}

Aslinda \& Leni, S. (2010). Pengantar sosiolinguistik. Bandung: Refika Aditama.

Alwi, H., et al. (2010). Tata bahasa baku bahasa Indonesia. Jakarta: Balai Pustaka.

Alwi, M., et al. (2013). Penelitian pendidikan. Lombok: PGSD STKIP Hamzanwadi Selong.

Chaer, A., \& Agustina, L. (2010). Sosiolinguistik perkenalan awal. Jakarta: Rineka Cipta.

Chaer, A. (2012). Linguistik umum edisi revisi. Jakarta: Rineka Cipta.

Chaer, A. (2015). Morfologi bahasa Indonesia. Jakarta: Rineka Cipta. 
Chaer, A. (2009). Sintaksis bahasa Indonesia. Jakarta: Rineka Cipta.

Moleong, L. J. (2007).Metodologi penelitian kualitatif edisi revisi. Bandung: Remaja Rosdakarya.

Miles M. B., \& Huberman, A. M. (1992). Analisis data kualitatif. Jakarta: Universitas Indonesia.

Patilima, H. (2011). Metode penelitian kualitatif. Bandung: Alfabeta.

Ramlan, M. (2009). Morfologi suatu tinjauan deskriptif. Yogyakarta: Karyono.

Sugiyono. (2010). Memahami penelitian kualitatif. Bandung: Alfabeta. 